\title{
ANALISIS PENGARUH BELANJA LANGSUNG DAN BELANJA TIDAK LANGSUNG TERHADAP PENINGKATAN EKONOMI SEKTOR KEUANGAN, REAL ESTATE, DAN JASA PERUSAHAAN DI KOTA MANADO (2007-2013) \\ Steffi Iksan, Rosalina A.M Koleangan, Een J. Walewangko. Fakultas Ekonomi Universitas Sam Ratulangi
}

\begin{abstract}
Alokasi belanja pemerintah sangat erat kaitannya dengan pembangunan yang terjadi di pusat maupun di daerah salah satunya adalah pembangunan dalam bidang ekonomi, tentu selain baik alokasi anggaran yang dikeluarkan pemerintah melalui belanja langsung dan belanja tidak langsung untuk pembangunan sector ekonomi maka akan semakin baik pula peningkatan atau pertumbuhan yang terjadi pada sector ekonomi tersebut yang secara agregat akan meningkatkan pertumbuhan ekonomi.

Dalam penelitian ini digunakan analisis regresi berganda untuk melihat seberap besar pengaruh belanja langsung dan belanja tidak mempengaruhi peningkatan sector keuangan, real estate dan jasa keuangan. Dan dari hasil penghitungan matematika didapatkan hasil bahwa belanja langsung tidak mempunyai korelasi positif dan signifikan terhadap peningkatan sector yang diteliti, begitu pun dengan alokasi belanja tidak langsung mempunyai korelasi positif namun tingkat signifikansinya masih kurang apabila dilihat secara parsial. Namun pada saat dilakukan penghitungan R square didapatkan angka 88,5 tingkat keterpengaruhan dua variable independent atau variable belanja belanja langsung dan tidak langsung terhadap variable dependent sector keuangan, real estate dan jasa perusahaan.
\end{abstract}

Kata kunci : Belanja Langsung, belanja tidak langsung, pertumbuhan ekonomi

Abstract

The allocation of government spending is closely associated with the development that occurs in the central and local levels one of which is the development in the field of economics, of course in addition to better budget allocation by the government through direct expenditures and indirect expenditures for the construction sector of the economy, the better the increase or growth that occurred in the economic sector which in aggregate would increase economic growth.

In this study used multiple regression analysis to see the influence seberap direct expenditure and expenditure does not affect the increase in the financial sector, real estate and financial services. And the results of mathematical calculations showed that direct spending does not have a positive and significant correlation to increased sectors studied, as was the allocation of indirect expenditure has positive correlation but still less than the level of significance when seen partially. However, at the time of calculation of figures obtained $\mathrm{R}$ square 88.5 percent influence level two independent variables or variable direct expenditure and indirect expenditure the dependent variable financial sector, real estate and business services.

Keywords: Direct expenditure, indirect expenditure, economic growth 


\section{Latar Belakang}

\section{PENDAHULUAN}

Otonomi daerah sejatinya adalah salah satu cara bagi daerah untuk dapat melaju ke tahapan perekonomian yang lebih maju. Dengan adanya otonomi, daerah bisa lebih memaksimalkan pembangunan ekonominya. Selain mendapat limpahan tanggung jawab dari pusat ke daerah, pemerintah daerah juga mendapat limpahan kewenangan dari pusat dalam bentuk desentralisasi. Dengan adanya konsep desentralisasi pemerintah daerah diharapkan dapat lebih memaksimalkan potensi-potensi daerah yang dimilik dan sebelumnya belum terkelola dengan maksimal. Hal ini diharapkan dapat menggenjot sektorsektor perekonomian yang dimiliki dan dapat mengantarkan daerah ke tingkat perekonomian yang lebih tinggi. Dengan kontribusi yang maksimal dari sektor-sektor ekonomi maka diharapakan sebuah daerah akan lebih meningkatkan kemandiriannya terhadap alokasi anggaran dari pusat, bahkan bisa memberi kontribusi dalam perekonomian nasional. Upaya ini tentu tak bisa lepas dari peran serta berbagai pihak mulai dari pemerintah sebagai pemegang tapuk kekuasaan dan pengguna anggaran, serta pihak swasta yang juga menanamkan investasinya di daerah, bahkan peran serta masyarakat luas juga memegang peranan penting dalam sebuah demokrasi ekonomi. Sebuah pembangunanan ekonomi adalah proses dimana pemerintah masyarakat serta pihak terkait mengelola dan memanfaatkan sumber daya yang secara maksimal serta membentuk lapangan kerja baru guna memaksimalkan potensi pertumbuhan ekonomi di dalam wilayah tersebut. Saat ini yang masih menjadi masalah kalsik daerah-daerah otonomi baru adalah masih tingginya tingkat kemandirian terhadap kucuran dana dari pemerintah pusat, jika dibandingkan dengan Pendapatan Asli Daerah (PAD) tingkat kemandirian daerah masih tergolong kurang.

Peran serta pemerintah dalam mengelola, memanfaatkan dan meningkatkan kotribusi sektot-sektor perekonomiannya tentu tidak bisa lepas dari pengalokasian belanja dalam Anggaran Pendapatan dan Belanja Daerah (APBD). APBD merupakan total anggaran sebuah daerah baik dari sisi pendapatan maupun dari sisi pengeluaran. Sumber dana dalam APBD berasal dari beberapa komponen utama diantaranya adalah Pendapatan Asli Daerah (PAD), yang bersumber dari pendapatan daerah seperti pajak langsung daerah, retribusi yang dipungut di daerah serta PAD lain yang sah. Kemudian dana transfer dari pemerintah pusat, yang terbagi dalam Dana Alokasi Umum (DAU) yang pengalokasiannya diserahkan sepenuhnya kepada pemerintah daerah, kemudian Dana Alokasi Khusus (DAK) yang pengalokasiannya ditujukan untuk program pemerintah pusat yang ada di daerah atau melalui usulan dari pemerintah daerah untuk kepentingan yang bisa digolongkan mendesak, seperti program rehabilitasi setelah bencana. Setelah itu ada pinjaman daerah serta pendapatan daerah lain yang sah.

Semua pendapatan dalam setahun ini kemudian menjadi Total Pendapatan Daerah (TPD) yang kemudian pengalokasiannya akan diserahkan ke Satuan Kerja Perangkat Daerah (SKPD) dan Dinas-dinas yang ada di daerah, setelah itu program serta anggaran yang sudah disusun kemudian disatukan dalam sebuah buku dengan judul Rencana Anggaran Pendapatan dan Belanja Daerah (RAPBD), kemudian dari pihak esksekutif akan mengajukan RAPBD tersebut ke pihak legislatif untuk kemudian dipelajari. Setelah semua proses dilalui di daerah RAPBD ini kemudian akan diusulkan ke Pemerintah Pusat melalui kementrian dalam negeri. Setelah itu baru akan muncul produk pengusulan anggaran yang berkekuatan hukum tetap berjudul APBD.

Dengan adanya APBD yang diusulkan dan dikelola langsung oleh pemerintah daerah semakin menacapkan manfaat dari Undang-Undang No 33 Tahun 2004 tentang perimbangan keuangan antara pemerintah pusat dan daerah telah digulirkan pada 1 Januari 2001. Adanya Undang-Undang tersebut telah mengakibatkan pergeseran paradigma penyelenggaraan pemerintah dari paradigma sentralistis ke arah desentralisasi yang ditandai dengan pemberian otonomi yang luas dan nyata kepada daerah.

Hal ini tentu menjadi jalan bagi pemerintah daerah untuk lebih maksimal dalam memanfaatkan dan mengelola sumber-sumber ekonomi yang dimilikinya, meskipun tidak sedikit masalah yang dihadapi dalam pelaksanaannya oleh karena itu, pemerintah mengeluarkan Undang-Undang No.32 Tahun 2004 tentang pemerintahan daerah dan Undang-Undang No.33 Tahun 2004 tentang perimbangan keuangan antara pemerintah pusat dan pemerintah daerah.

Pembangunan daerah dengan memanfaatkan sebaik mungkin APBD untuk memacu pertumbuhan sektor-sektor ekonomi yang secara agregrat akan menunjang pertumbuhan ekonomi setiap tahunnya tentu haru menjadi concern utama pemerintah, terlebih pemerintah daerah sebab selain hak untuk mengelola dan memanfaatkan sumber daya yang dimiliki sebaik-baiknya pemerintah daerah juga mendapat limpahan tanggung jawab dari pemerintah pusat dalam bentuk pelayanan yang lebih baik dan dekat dengaan masyarakat. Yang juga dikenal dengan istilah desentralisasi. Desentralisasi fiscal, dapat pula diartikan sebagai suatu proses distribusi anggaran dari pemerintah yang lebih tinggi kepada pemerintah yang lebih 
rendah untuk kemudian dikelola guna mendukung fungsi atau tugas pemerintahan dan pelayanan public sesuai dengan banyaknya wewenang bidang pemerintahan yang diberikan atau dilimpahkan oleh pemerintah pusat (Saragih $2003: 82$ ).

Dalam hubungannya, antara pemerintah pusat dan daerah menyangkut desentralisasi fiscal, dana perimbangan merupakan salah satu komponen utama yang mempengaruhi tingkat kemampuan daerah tersebut dalam mecukupi kebutuhan anggaran belanjanya di setiap periode. Perimbangan keuangan merupakan salah satu bentuk hubungan antara pemerintah pusat dan daerah dari sekian banyak hubungan yang dimilikinya, hubungan ini sendiri bersifat (intergovernmental fiscal relation system), sebagai salah satu bentuk kerjasama dalam pendelegasian wewenang pemerintah.

Meskipun dalam prakteknya sebagian besar daerah masih bergantung pada alokasi dana transfer dari pemerintah pusat dan masih berjuang memaksimalkan sumber-sumber PAD yang dimiliki. Hal ini tentu mengindikasikan bahwa kemampuan daerah untuk dapat mengatur perekonomian serta potensi yang dimilikinya masih sangat terbatas karena factor ketergantungan kepada pemerintah pusat yang masih amat besar, sehingga banyak kebijakan dari pemerintah pusat dalam pengelolaan potensi sumber keuangan harus diikuti oleh pemerintah daerah, dan sumber-sumber keuangan yang potensial masih tetap dikuasai oleh pemerintah pusat (Yani, $2002: 3$ ).

Sulawesi Utara adalah daerah yang berada di Timut Indonesia saat ini merupakan salah satu daerah yang tengah menjadi sorotan karena kegiatan perekonomian yang terjadi dengan sangat cepat yang menyebabkan pertumbuhan ekonomi ikut terpacu. Letak geografis di bibir pasifik menjadikannya daerah yang berpotensi menjadi pusat perdagangan bukan hanya kawasan Indonesia Timur namun juga pusat perdagangan dunia. Saat ini guna menjadikan Sulawesi Utara kian dikenal di mata dunia berbagai kegiatan serta iven yang memacu pertumbuhan ekonomi tengah gencar-gencarnya dilakukan baik oleh pemerintah, swasta, maupun masyarakat umum hal ini tentu dilakukan bukan hanya demi keuntungan sesaat semata namun juga membuka akses global ke seluruh pelosok dunia dengan Manado sebagai pintu masuknya. Manado sendiri pasca otonomi daerah terus menunjukan perkembangan yang signifikan dari segi pertumbuhan ekonominya maupun dari tingkat kemandirian terhadap dana transfer dari pemerintah pusat.

Tabel 1 Pendapatan Asli Daerah Kota Manado 2008-2012

\begin{tabular}{|l|l|}
\hline 2008 & 54.715 .561 .525 \\
\hline 2009 & 73.898 .733 .040 \\
\hline 2010 & 72.404 .996 .767 \\
\hline 2011 & 90.828 .438 .199 \\
\hline 2012 & 134.721 .720 .942 \\
\hline
\end{tabular}

Sumber : BPS Sulut

Dalam tabel diatas dapat dilihat jumlah pendapatan asli daerah terus mengalami peningkatan dari tahun ke tahun , bahkan dalam table data awal menunjukan peningkatan yang cukup signifikan mencapai $250 \%$ lebih hanya dalam waktu lima tahun, hal ini tentu sejalan dengan pengeluaran pemerintah baik belanja langsung maupun belanja tidak langsung yang melalui pengalokasian anggaran belanja tersebut akan meningkatakn pertumbuhan di sector-sektor ekonomi potensial yang secara agregat akan memajukan perekonomian dan tentu saja menggenjot PAD yang secara kumulatif akan meningkatankan kemandirian pemerintah daerah terhadap pusat. Dan kemudian dapat lebih memaksimalkan pengelolaan sumber-sumber daya yang ada secara maksimal dengan jumlah anggaran yang lebih besar dari sebelumnya. Dengan tersedianya anggaran di tangan pemerintah maka kemampuan untuk meningkatkan pertumbuhan ekonomi juga akan semakin tinggi, apalagi melihat perkembangan kota Manado yang semakin pesat dari tahun ke tahun, bahkan pada era 2000an pertumbuhan ekonomi di kota Manado tercatat selalu mengalami pertumbuhan yang pesat, bahkan selalu mencatatkan angka pertumbuhan ekonomi di atas 10 persen setiap tahunmya. Sehingga menjadi menarik untuk melihat seberapa besar peranan pemerintah sebagai pemegang kuasa penggunaan anggaran serta pembuat kebijakan dalam mempercepat, menggenjot pertumbuhan ekonomi yang terjadi di Kota Manado, bahkan juga menjaga kestabilan pertumbuhan ekonomi yang terjadi yang pada agregatnya nanti akan membuat peningkatan kesejahteraan masyarakat kota Manado kedepan

\section{Rumusan Masalah}

Tujuan utama dari pelaksanaan Otonomi Daerah, adalah untuk membagi beban serta tanggung jawab di daerah yang bersangkutan, agar jalannya pemerintahan serta pelayanan masyarakat yang lebih terfokus 
karena pemerintah di daerah tentu lebih mengetahui permasalahan serta kebutuhan di daerah yang bersangkutan. Disamping itu Daerah juga dituntut untuk dapat mengelola serta mengurus anggaran rumah tangganya sendiri. Hal ini menjadi menarik untuk diteliti guna melihat apakah kemampuan fiskal di daerah lebih berkembang selama Otonomi daerah, atau masih tetap mengandalkan kontribusi fiskal dari Pemerintah pusat untuk menjalankan Pemerintahan di Daerah. Dengan menigkatakan kemandiriannya melalui peningkatan sector-sektor ekonomi potensial.

Berdasarkan latar belakang yang ada maka rumusan masalah yang akan dibahas adalah : Bagaimana pengaruh alokasi Belanja langsung dan Belanja tidak Langsung terhadap peningkatan sector keuangan, real estate dan jasa perusahaan di Kota Manado 2007-2013?

\section{Tujuan Penelitian}

Yang menjadi tujuan penelitian ini adalah untuk mengetahui seberapa besar pengaruh alokasi belanja langsung dan tidak langsung terhadap peningkatan ekonomi sector keuangan, real estate dan jasa perusahaan.

\section{Manfaat Penelitian}

Sebagai bahan masukan bagi pemerintah Kota Manado untuk mengetahui perkembangan perekonomiannya, yang bisa berguna untuk informasi dalam pengembangan daerah.

Untuk digunakan pihak yang berkepentingan untuk menganalisa masalah - masalah yang berhubungan dengan Pengelolaan fiskal Kota Manado.

Sebagai bahan referensi bagi penulis lain maupun mahasiswa yang akan melakukan penelitian terkait masalah fiscal.

\section{LANDASAN TEORY}

\section{Keuangan Daerah \\ Pengertian dan Ruang Lingkup Keuangan Daerah}

Dalam arti sempit, keuangan daerah yakni terbatas pada hal-hal yang berkaitan dengan APBD. Oleh sebab itu keuangan daerah identik dengan APBD. Menurut Mamesah dalam Halim (2004: 18), Keuangan Daerah dapat diartikan sebagai semua hak dan kewajiban pemerintah yang dapat dinilai dengan uang. Demikian pula dengan segala sesuatu baik berupa uang maupun barang yang dapat dijadikan kekayaan daerah yang lebih tinggi serta pihak-pihak lain sesuai peraturan perundangan yang berlaku.

Berdasarkan PP Nomor 58 Tahun 2005, Keuangan Daerah adalah semua hak dan kewajiban daerah dalam rangka penyelenggaraan pemerintah daerah yang dapat dinilai dengan uang termasuk didalamnya segala bentuk kewajiban daerah tersebut perlu dikelola dalam suatu sistem pengelolaan keuangan daerah. Pengelolaan keuangan daerah merupakan subsistem dari sistem pengelolaan keuangan negara dan merupakan elemen pokok dalam penyelenggaraan pemerintah daerah.

Menurut Halim (2004: 20), ruang lingkup keuangan daerah terdiri dari keuangan daerah yang dikelola langsung dan kekayaan daerah yang dipisahkan. Yang termasuk dalam keuangan yang dikelola langsung adalah APBD dan barang-barang inventaris milik daerah. Sedangkan keuangan daerah yang dipisahkan meliputi Badan Usaha Milik Daerah (BUMD).

\section{Pengelolaan Keuangan Daerah}

Dalam ketentuan umum pada PP Nomor 58 Tahun 2005, Pengelolaan Keuangan Daerah adalah keseluruhan kegiatan yang meliputi perencanaan, pelaksanaan, penatausahaan, pelaporan dan pertanggungjawaban, pengawasan daerah. Pengelolaan keuangan daerah dalam hal ini mengandung beberapa kepengurusan dimana kepengurusan umum atau yang sering disebut pengurusan administrasi dan kepengurusan khusus atau juga sering disebut pengurusan bendaharwan. Dalam pengelolaan anggaran/keuangan daerah harus mengikuti prinsip-prinsip pokok anggaran sektor publik. Pada Permendagri Nomor 26 Tahun 2006 tentang Pedoman Penyusunan APBD Tahun Anggaran 2007 menyatakan bahwa "APBD harus disusun dengan memperhatikan prinsip-prinsip pokok anggaran sektor publik, sebagai berikut: (a) Partisipasi Masyarakat, (b) Transparansi dan Akuntabilitas Anggaran, (c) Disiplin Anggaran, (d) Keadilan Anggaran, (e) Efisiensi dan Efektivias Anggaran dan (f) Taat Asas".

Pengelolaan Keuangan Daerah adalah keseluruhan kegiatan yang meliputi perencanaan, pelaksanaan, penatausahaan, pelaporan, pertanggungjawaban, dan pengawasan keuangan daerah (PP 58/2005, pasal 1).

\section{Pertumbuhan Ekonomi}

Pengertian Pertumbuhan Ekonomi 
Secara umum, pertumbuhan ekonomi didefenisikan sebagai peningkatan kemampuan dari suatu perekonomian dalam memproduksi barang-barang dan jasa-jasa. Pertumbuhan ekonomi adalah salah satu indikator yang amat penting dalam melakukan analisis tentang pembangunan ekonomi yang terjadi pada suatu negara. Pertumbuhan ekonomi menunjukkan sejauh mana aktivitas perekomian akan menghasilkan tambahan pendapatan masyarakat pada suatu periode tertentu. Karena pada dasarnya aktivitas perekonomian adalah suatu proses penggunaan faktor-faktor produksi untuk menghasilkan output, maka proses ini pada gilirannya akan menghasilkan suatu aliran balas jasa terhadap faktor produksi yang dimiliki oleh masyarakat. Dengan adanya pertumbuhan ekonomi maka diharapkan pendapatan masyarakat sebagai pemilik faktor produksi juga akan meningkat.

Dengan perkataan lain bahwa pertumbuhan ekonomi lebih menunjuk kepada perubahan yang bersifat kuantitatif (quantitative change) dan biasanya diukur dengan menggunakan data Produk Domestik Bruto (PDB) atau pendapatan atau nilai akhir pasar (total market value) dari barang-barang akhir dan jasa-jasa (final goods and services) yang dihasilkan dari suatu perekonomian selama kurun waktu tertentu (biasanya satu tahun).

Perlu diketahui bahwa pertumbuhan ekonomi berbeda dengan pembangunan ekonomi, kedua istilah ini mempunyai arti yang sedikit berbeda. Kedua-duanya memang menerangkan mengenai perkembangan ekonomi yang berlaku. Tetapi biasanya, istilah ini digunakan dalam konteks yang berbeda. Pertumbuhan selalu digunakan sebagai suatu ungkapan umum yang menggambarkan tingkat perkembangan sesuatu negara, yang diukur melalui persentasi pertambahan pendapatan nasional riil. Istilah pembangunan ekonomi biasanya dikaitkan dengan perkembangan ekonomi di negara-negara berkembang. Dengan perkataan lain, dalam mengartikan istilah pembangunan ekonomi, ahli ekonomi bukan saja tertarik kepada masalah perkembangan pendapatan nasional riil, tetapi juga kepada modernisasi kegiatan ekonomi, misalnya kepada usaha merombak sektor pertanian yang tradisional, masalah mempercepat pertumbuhan ekonomi dan masalah perataan pembagian pendapatan (Sukirno, 2006:423)

\section{Teori Tahap-Tahap Pertumbuhan Ekonomi}

Teori ini dimunculkan oleh Prof. W.W. Rostow yang memberikan lima tahap dalam pertumbuhan ekonomi. Analisis ini didasarkan pada keyakinan bahwa pertumbuhan ekonomi akan tercapai sebagai akibat dari timbulnya perubahan yang fundamental dalam corak kegiatan ekonomi, juga dalam kehidupan politik dan hubungan sosial dalam suatu masyarakat dan negara.

Adapun kelima tahapan tersebut adalah:

1) Tahap Masyarakat Tradisional (The Traditional Society) Rostow mengartikan bahwa masyarakat tradisional sebagai suatu masyarakat yang:

a) Cara-cara memproduksi yang relatif primitif dan sikap masyarakat serta cara hidupnya yang sangat dipengaruhi oleh nilai-nilai yang dicetuskan oleh cara pemikiran yang bukan rasional, tetapi oleh kebiasaan yang telah berlaku secara turun-temurun. Tingkat produksi yang dapat dicapai masih sangat terbatas, karena ilmu pengetahuan dan teknologi modern belum ada atau belum digunakan secara sistematis dan teratur.

b) Tingkat produksi perkapita dan tingkat produktivitas per pekerja masih sangat terbatas. Oleh sebab itu sebagian besar dari sumber-sumber daya masyarakat digunakan untuk kegiatan dalam sektor pertanian. Dalam sektor ini struktur sosialnya sangat bersifat hierarkis, sehingga mobilitas secara vertikal dalam masyarakat sedikit sekali.

c) Kegiatan politik dan pemerintahan terdapat di daerah-daerah dipegang oleh tuan-tuan tanah yang berkuasa, dan kebijakan-kebijakan dari pemerintah pusat selalu dipengaruhi oleh pandangan tuan-tuan tanah di berbagai daerah tersebut.

2) Tahap Prasyarat Lepas Landas

Tahap ini adalah tahap sebagai suatu masa transisi pada saat masyarakat mempersiapkan dirinya ataupun dipersiapkan dari luar untuk mencapai pertumbuhan yang mempunyai kekuatan untuk terus berkembang (self-sustain growth). Pada tahap ini dan sesudahnya pertumbuhan ekonomi akan berlaku secara otomatis. Tahap prasyarat lepas landas ini dibedakan menjadi dua, yaitu:

a) Tahap prasyarat untuk lepas landas yang dicapai oleh negara-negara Eropa, Asia, Timur Tengah, dan Afrika yang dilakukan dengan merubah struktur masyarakat tradisional yang sudah ada.

b) Yang dinamakan Rostow bom free, yaitu prasyarat lepas landas yang dicapai Amerika Serikat, Kanada, Australia dan Selandia Baru, dengan tanpa harus merombak sistem masyarakat yang tradisional, karena masyarakat negara-negara itu terdiri dari emigran yang telah mempunyai sifat-sifat yang diperlukan oleh masyarakat untuk mencapai tahap prasyarat lepas landas. 
3) Tahap Lepas Landas (Take Off)

Adalah suatu tahap interval dimana tahap masyarakat tradisional dan tahap prasyarat untuk lepas landas telah dilewati. Pada periode ini, beberapa penghalang pertumbuhan dihilangkan dan kekuatan-kekuatan yang menimbulkan kemajuan ekonomi diperluas dan dikembangkan, serta mendominasi masyarakat sehingga menyebabkan efektivitas investasi dan meningkatnya tabungan masyarakat.

Ciri-ciri tahap lepas landas yaitu:

a) Adanya kenaikan dalam penanaman modal investasi (yang produktif, dari 5\% atau kurang, menjadi 10\% dari Produk Nasional Neto). NNP=GNP-D (penyusutan).

b) Adanya perkembangan beberapa sektor industri dengan laju perkembangan yang tinggi.

c) Adanya atau terciptanya suatu kerangka dasar politik, sosial dan institusional yang akan menciptakan: 1) Kenyataan yang membuat perluasan di sektor modern. 2) Potensi ekonomi ekstern sehingga menyebabkan petumbuhan terus-menerus berlangsung.

4) Tahap Gerakaan ke Arah Kedewasaan (The Drive of Maturity)

Gerakan ke arah kedewasaan diartikan sebagai suatu periode ketika masyarakat secara efektif menerapkan teknologi modern dalam mengolah sebagian besar faktor-faktor produksi dan kekayaan alamnya.

Ciri-ciri gerakan ke arah kedewasaan adalah:

a) Kematangan teknologi, dimana struktur keahlian tenaga kerja mengalami perubahan.

b) Sifat kepemimpinan dalam perusahaan mengalami perubahan.

c) Masyarakat secara keseluruhan merasa bosan dengan keajaiban yang diciptakan oleh industrialisasi, karena berlakunya hukum kegunaan batas semakin berkurang.

5) Tahap Masa Konsumsi Tinggi.

Pada masa ini perhatian masyarakat mengarah kepada masalah-masalah yang berkaitan dengan konsumsi dan kesejahteraan masyarakat dan bukan lagi kepada masalah produksi. Leading sectors, bergerak ke arah barang-barang konsumsi yang tahan lama serta jasa-jasa. Pada periode ini terdapat tiga macam tujuan masyarakat untuk mendapatkan sumber-sumber daya yang tersedia dan dukungan politis, yaitu:

a) Memperbesar kekuasaan dan pengaruh negara tersebut ke luar negeri dan kecenderungan ini dapat berakhir pada penaklukan atas negara-negara lain.

b) Menciptakan suatu welfare state, yaitu kemakmuran yang lebih merata kepada pendukungnya dengan cara mengusahakan terciptanya pembagian pendapatan yang lebih merata melalui sistem perpajakan yang progresif, dalam sistem perpajakan seperti ini makin besar pendapatan maka makin besar pajaknya.

c) Mempertinggi tingkat konsumsi masyarakat di atas konsumsi dasar yang sederhana atas makanan, pakaian, rumah keluarga secara terpisah dan juga barang-barang konsumsi tahan lama serta barang-barang mewah.

\section{METODE PENELITIAN}

\section{Variabel Penelitian dan Definisi Operasional \\ Jenis dan Sumber Data}

Data yang digunakan dalam penelitian ini adalah data sekunder atau mengambil data yang sudah tersedia di instansi tertentu yang sesuai dengan jenis penelitian dan dalam penelitian ini mengambil data dari Badan Perencanaan dan Pembangunan Kota Manado (Bappeda) dan dari badan pusat Statistik (BPS) Provinsi Sulawesi Utara.

\section{Metode Pengumpulan Data}

Metode pengambilan data sekunder, data dikumpulkan dengan metode dokumentasi. Ini dilakukan dengan mengumpulkan, mencatat dan menghitung data-data yang berhubungan dengan penelitian. Penelitian ini mengambil data dari APBD Kota Manado tahun 2007 sampai 2013 dan statistic PDRB di tahun yang sama.

\section{Metode Analisis}

Penelitian ini dengan menggunakan pendekatan kuantitatif. Secara umum, pendekatan kuantitatif lebih fokus pada tujuan untuk generalisasi, dengan melakukan pengujian statistik dan steril dari pengaruh subjektif peneliti (Sekaran, 1992). Alat analisis yang digunakan dalam penelitian ini adalah analisis regresi linier berganda. Analisis regresi berganda adalah analisis mengenai beberapa variabel independen dengan satu variabel dependen.

Secara umum, analisis regresi adalah analisis mengenai variabel independen dengan variabel dependen yang bertujuan untuk mengestimasi nilai rata-rata variabel dependen berdasarkan nilai variabel independen 
yang diketahui (Gujarati, 2003). Teknik yang digunakan untuk mencari nilai persamaan regresi yaitu dengan analisis Least Squares (kuadrat terkecil) dengan meminimalkan jumlah dari kuadrat kesalahan.

Dalam analisis regresi selain mengukur seberapa besar hubungan antara variabel independen dengan variabel dependen, juga menunjukkan bagaimana hubungan antara variabel independen dengan dependen, sehingga dapat membedakan variabel independen dengan variabel dependen tersebut (Ghozali, 2006). Dimana dalam penelitian ini, tiga komponen dari pendapatan daerah yaitu pajak daerah, dana retribusi dan PAD lain yang sah sebagai variabel independen, akan dianalisis pengaruhnya terhadap alokasi belanja daerah yang diukur belanja langsung sebagai variabel dependen.

Beberapa langkah yang dilakukan dalam analisis regresi linier masing- masing akan dijelaskan di bawah ini:

\section{Analisis Regresi Linier Berganda}

Dalam penelitian ini data dianalisis menggunakan analisis regresi linier berganda (multiple linier regression). Data diolah dengan program SPSS 20 for Windows. Teknik ini digunakan untuk menganalisis pengaruh variabel independen terhadap variabel dependen. Formula dalam penelitian ini adalah sebagai berikut:

\begin{tabular}{|c|c|c|}
\hline & & $\mathrm{Y}=\alpha+\beta_{1} \mathrm{X}_{1}+\beta_{2} \mathrm{X}_{2}++\varepsilon$ \\
\hline $\begin{array}{l}\text { Dimana : } \\
\text { Y }\end{array}$ & $=$ & \\
\hline$\alpha$ & $=$ & Konstanta \\
\hline$\beta_{1}$ & $=$ & Koefisien regresi untuk $X_{1}$ \\
\hline$\beta_{2}$ & $=$ & Koefisien regresi untuk $X_{2}$ \\
\hline $\mathrm{X}_{1}$ & $=$ & Belanja Langsung \\
\hline $\mathrm{X}_{2}$ & $=$ & Belanja Tidak Langsung \\
\hline & $=$ & Variabel sisa yang tidak diteliti \\
\hline
\end{tabular}

\section{Statistik Deskriptif}

Penyajian statistik deskriptif bertujuan agar dapat dilihat profil dari data penelitian tersebut dengan hubungan yang ada antar variabel yang digunakan dalam penelitian tersebut. Dalam penelitian ini variabel yang digunakan adalah Pendapatan pajak, retribusi dan PAD lain yang sah serta belanja langsung.

\section{Uji Asumsi Klasik}

Pengujian regresi linier berganda dapat dilakukan setelah model dari penelitian ini memenuhi syarat-syarat yaitu lolos dari asumsi klasik. Syarat-syarat yang harus dipenuhi adalah data tersebut harus terdistribusikan secara normal, tidak mengandung multikoloniaritas, dan heterokedastisitas. Untuk itu sebelum melakukan pengujian regresi linier berganda perlu dilakukan lebih dahulu pengujian asumsi klasik, yang terdiri dari:

\section{Uji Normalitas}

Pengujian normalitas memiliki tujuan untuk menguji apakah dalam model regresi, variabel penganggu atau residual memiliki distribusi normal. Seperti diketahui bahwa uji t mengasumsikan bahwa nilai residual mengikuti distribusi normal. Kalau asumsi ini dilanggar maka uji statistik menjadi tidak valid untuk jumlah sampel kecil.

Untuk menguji normalitas data, penelitian ini menggunakan analisis grafik. Pengujian normalitas melalui analisis grafik adalah dengan cara menganalisis grafik normal probability plot yang membandingkan distribusi kumulatif dari distribusi normal. Distribusi normal akan membentuk satu garis lurus diagonal, dan ploting data residual akan dibandingkan dengan garis diagonal. Data dapat dikatakan normal jika data atau titik-titk terbesar di sekitar garis diagonal dan penyebarannya mengikuti garis diagonal.

Pada prinsipnya normalitas dapat dideteksi dengan melihat penyebaran data (titik) pada sumbu diagonal dari grafik atau dengan melihat histrogram dari residualnya. Dasar pengambilan keputusan:

Jika data menyebar disekitar garis diagonal dan mengikuti arah garis diagonal atau grafik histrogramnya menunjukan pola distribusi normal, maka model regresi memenuhi asumsi normalitas. Jika data menyebar lebih jauh dari diagonal dan/atau tidak mengikuti arah garis diagonal atau grafik histrogram tidak menunjukkan pola distribusi normal, maka model regresi tidak memenuhi asumsi normalitas (Ghozali, 2006). 
Uji statistik yang dapat digunakan untuk menguji normalitas residual adalah uji statistik non-parametrik Kolmogrov-Smirnov (K-S). Jika hasil Kolmogrov-Smirnov menunjukkan nilai signifikan diatas 0,05 maka data residual terdistribusi dengan normal. Sedangkan jika hasil Kolmogrov-Smirnov menunjukkan nilai signifikan dibawah 0,05 maka data residual terdistribusi tidak normal (Ghozali, 2006).

\section{Uji Multikolinearitas}

Uji Multikolonieritas bertujuan untuk menguji apakah model regresi ditemukan adanya korelasi antar variabel bebas (Ghozali, 2006). Uji multikolonieritas ini digunakan karena pada analisis regresi terdapat asumsi yang mengisyaratkan bahwa variabel independen harus terbebas dari gejala multikolonieritas atau tidak terjadi korelasi antar variabel independen.

Cara untuk mengetahui apakah terjadi multikolonieritas atau tidak yaitu dengan melihat nilai Tolerance dan Variance Inflation Factor (VIF). Kedua ukuran ini menunjukkan setiap variabel independen manakah yang dijelaskan oleh variabel independen lainnya. Dalam pengertian sederhana setiap variabel independen menjadi variabel dependen (terikat) dan diregresi terhadap variabel independen lainnya. Tolerance mengukur variabilitas variabel independen yang terpilih yang tidak dijelaskan oleh variabel independen lainnya. Jadi nilai Tolerance yang rendah sama dengan nilai VIF tinggi (karena VIF $=1 /$ Tolerance). Nilai cutoff yang umum dipakai untuk menunjukkan adanya multikolinearitas adalah nilai Tolerance $<0,10$ atau sama dengan nilai VIF>10 (Ghozali, 2006).

\section{Uji Autokorelasi}

Uji autokorelasi bertujuan menguji apakah dalam model regresi berganda linier ada korelasi antara kesalahan penganggu pada periode $\mathrm{t}$ dengan kesalahan penganggu pada periode $\mathrm{t}-1$ (sebelumnya). Autokorelasi muncul karena observasi yang berurutan sepanjang waktu berkaitan satu sama lain. Jika ada masalah autokorelasi, maka model regresi yang seharusnya signifikan, menjadi tidak layak untuk dipakai (Singgih Santoso, 2000).

Autokorelasi dalam penelitian ini menggunakan uji statistik Durbin Watson. Singgih (2000), bila angka DW diantara -2 samapai +2, berarti tidak terjadi autokorelasi. Menurut Ghozali (2006), untuk mendeteksi ada atau tidaknya autokorelasi bisa menggunakan Uji Durbin-Watson (DW test)

\section{Uji Heteroskedastisitas}

Pengujian ini memiliki tujuan untuk menguji apakah dalam model regresi terjadi ketidaksamaan variance dari residual satu pengamatan ke pengamatan yang lain atau untuk melihat penyebaran data. Jika variance dari residual satu pengamatan ke pengamatan yang lain tetap, maka disebut Homokedastisitas dan jika berbeda disebut Heteroskedastisitas. Model regresi yang baik adalah tidak terdapat heteroskedastisitas.

Uji ini dapat dilakukan dengan melihat gambar plot antara nilai prediksi variabel independen (ZPRED) dengan residualnya (SRESID). Apabila dalam grafik tersebut tidak terdapat pola tertentu yang teratur dan data tersebar secara acak di atas dan di bawah angka 0 pada sumbu Y, maka diidentifikasikan tidak terdapat heteroskedastisitas (Ghozali,2006).

\section{Model Regresi}

Alat analisis yang digunakan adalah analisis regresi berganda linier yang digunakan untuk melihat pengaruh pendapatan yaitu PAD dan DAU terhadap pengeluaran pemerintah yang berupa alokasi belanja daerah (belanja langsung dan belanja tidak langsung). Data diolah dengan bantuan software SPSS seri 21.00.

Pengujian hipotesis dilakukan dengan menggunakan model analisis regresi variabel independen terhadap variabel dependen (sekaran, 1992). Ada dua persamaan regresi, persamaan regresi adalah:

\section{Uji Hipotesis}

Ketepatan fungsi regresi sampel dalam menaksir nilai aktual dapat diukur dari Goodness of Fitnya. Secara statistik, setidaknya ini dapat diukur dari nilai koefisien determinasi, nilai statistik F dan nilai statistik t. Perhitungan statistik disebut signifikan secara statistik apabila nilai uji statistiknya berada dalam daerah kritis (daerah dimana Ho ditolak). Sebaliknya disebut tidak signifikan bila nilai uji statistiknya berada dalam daerah dimana Ho diterima (Ghozali, 2006).

\section{Koefisien Determinasi}


Koefisien determinasi $\left(\mathrm{R}^{2}\right)$ pada intinya mengukur seberapa jauh kemampuan model dalam menerangkan variasi variabel independen. Koefisien determinasi ini digunakan karena dapat menjelaskan kebaikan dari model regresi dalam memprediksi variabel dependen. Semakin tinggi nilai koefisien determinasi maka akan semakin baik pula kemampuan variabel independen dalam menjelaskan variabel dependen (Ghozali, 2006).

Nilai koefisien determinasi adalah antara nol dan satu. Nilai $\mathrm{R}^{2}$ yang kecil berarti kemampuan variabelvariabel independen dalam menjelaskan variasi variabel dependen amat terbatas. Nilai yang mendekati satu berarti variabel- variabel independen memberikan hampir semua informasi yang dibutuhkan untuk memprediksi variasi variabel dependen.

\section{Uji Signifikansi Simultan (Uji Statistik F)}

Uji Statistik F pada dasarnya menunjukkan apakah semua variabel independen atau bebas yang dimasukkan dalam model mempunyai pengaruh secara bersama-sama terhadap variabel dependen (Ghozali, 2006). Cara untuk mengetahuinya yaitu dengan membandingkan nilai $\mathrm{F}$ hitung dengan nilai $\mathrm{F}$ tabel. Apabila nilai $\mathrm{F}$ hitung lebih besar daripada nilai $\mathrm{F}$ tabel, maka hipotesis alternatif diterima artinya semua variabel independen secara bersama-sama dan signifikan mempengaruhi variabel dependen.

\section{Uji Signifikansi Parameter Individual (Uji Statistik t)}

Uji statistik t pada dasarnya menunjukkan seberapa jauh pengaruh satu variabel independen secara individual dalam menerangkan variasi variabel dependen (Ghozali, 2006). Uji statistik t ini digunakan karena untuk memperoleh keyakinan tentang kebaikan dari model regresi dalam memprediksi.

Cara untuk mengetahuinya yaitu dengan membandingkan nilai $\mathrm{t}$ hitung dengan nilai $\mathrm{t}$ tabel. Apabila nilai $\mathrm{t}$ hitung lebih besar dibandingkan dengan nilai t tabel maka berarti $\mathrm{t}$ hitung tersebut signifikan artinya hipotesis alternatif diterima yaitu variabel independen secara individual mempengaruhi variabel dependen. Selain itu, bisa juga dilakukan dengan melihat $p$-value dari masing-masing variabel. Hipotesis diterima

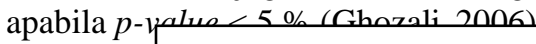

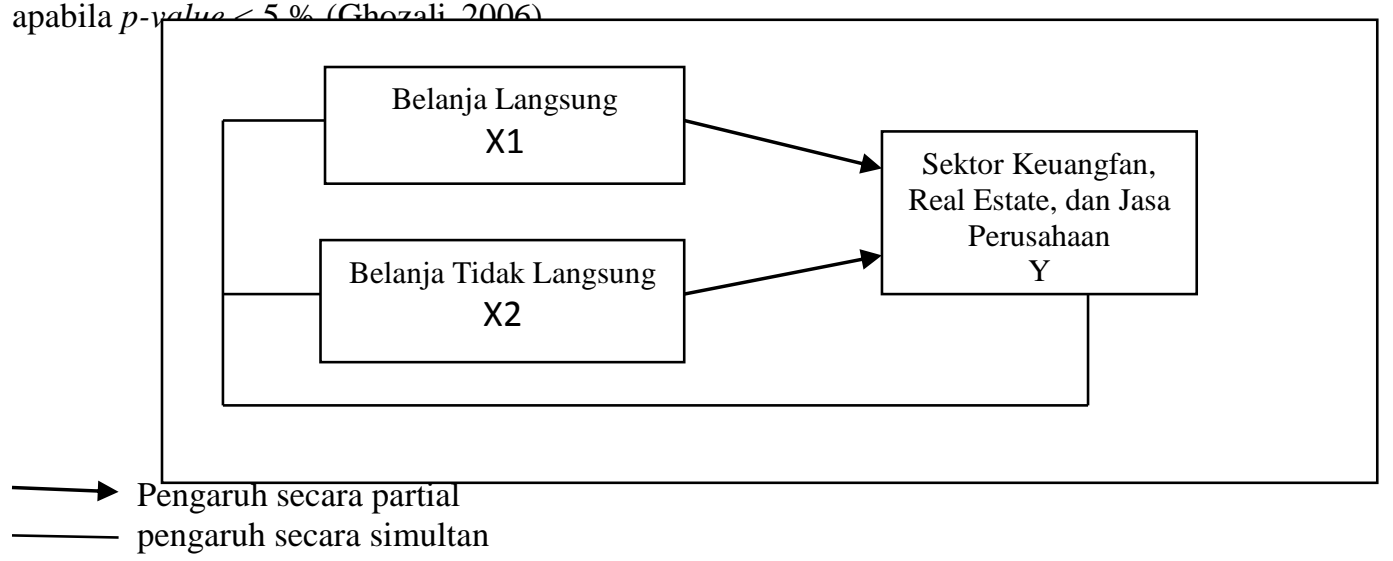

\section{HASIL PENELITIAN DAN PEMBAHASAN}

\section{Hasil Penelitian}

Dari hasil penelitian tentang pengaruh pajak daerah,retribusi daerah dan PAD lain yang sah terhadap belanja langsung ialah sebagai berikut

\section{Pengujian Asumsi klasik}

Untuk memperoleh hasil regresi berganda yang baik maka terlebih dahulu digunakan uji asumsi klasik, untuk menguji variable belanja langsung (X1) belanja tidak langsung (X2) dan sub-sektor transportasi (Y) yang akan diteliti.

\section{Multikolerasi}

Tabel 2 multikorelasi

Correlations

Partial
Collinearity Statistics

Tolerance

VIF




\begin{tabular}{|l|l|l|l|}
\hline & & & \\
.913 & .619 & .498 & 2.010 \\
.274 & .079 & .498 & 2.010 \\
\hline
\end{tabular}

a. Dependent Variable: Sektor keuangan, real estate dan jasa keuangan

Coefficients (a) Sumber data : Pengolahan Data 2015

Dilihat dari tabel 4.1 Coefficients nilai VIF pada Output menunjukkan keberadaan multikolinearitas.

Bila VIF $<10,00$ maka tidak terjadi gejala Multikolerasi

Bila VIF > 10,00 maka terjadi gejala Multikolerasi

Dengan Hasil :

Nilai Tolerance : X1 Belanja tidak langsung $\quad=0.498$

: X2 Belanja langsung $\quad=0,498$

Nilai VIF $\quad:$ X1 Belanja tidak langsung $\quad=2.010$

:X2 Belanja Langsung $\quad=2.010$

\section{Diagram Uji Heterokoledasitas}

Scatterplot

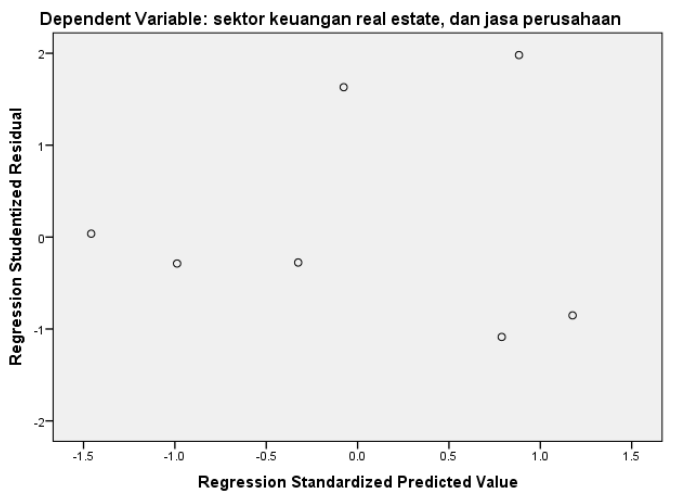

Gambar 2 Kurva Uji Heterokedastisitas hasil Model Penelitian

Dari diagram diatas tersebut terlihat bahwa penyebaran residual tidak teratur. Hal tersebut terlihat pada plot yang terpancar dan tidak membentuk pola tertentu. Dengan hasil demikian, kesimpulan yang biasa diambil adalah bahwa tidak terjadi gejala homokedastisitas atau persamaan regresi memenuhi asumsi heterokedatisitas.

\section{Uji Autokorelasi}

Autokorelasi merupakan korelasi antara anggota observasi yang disusun menurut waktu atau tempat. Model regresi yang baik seharusnya tidak terjadi autokorelasi. Menurut Singgih Santoso (2004 :219) untuk mengetahui adanya autokorelasi digunakan uji Durbin Watson (DW test). Model regresi dikatakan tidak terdapat korelasi apabila nilay Durbin Watson berkisar 1,55 sampai 2,46 (untuk $\mathrm{N}<15$ )

Tabel 3 Uji Aotukorelasi

\begin{tabular}{|c|c|c|c|c|c|c|}
\hline \multirow[b]{2}{*}{ Model } & \multicolumn{5}{|l|}{ Change Statistics } & \multirow[b]{2}{*}{$\begin{array}{l}\mathrm{F} \text { Durbin- } \\
\text { Watson }\end{array}$} \\
\hline & R Square Change & F Change & df1 & df2 & $\begin{array}{l}\text { Sig. } \\
\text { Change }\end{array}$ & \\
\hline 1 & .923 & 24.002 & 2 & 4 & .006 & 1.958 \\
\hline
\end{tabular}

a. Predictors: (Constant), belanja langsung, belanja tidak langsung

$b$. b. Dependent Variable: sektor keuangan real estate, dan jasa perusahaan

Sumber data : Pengolahan Data 2015 
Pada analisis regresi telihat bahwa nilai DW 1.958 dan nilai DL 0.1714 , dan DU 3,149.DL < DW < DU yakni 0.610 DL, 1.958 DW, 1,400 DU. DW berada pada antara DL dan DU dan berada pada titik keraguraguan. Maka dapat disimpulkan bahwa terdapat gejala autokorelasi yang lemah.

\section{HasilAnalisis Regresi Linear Berganda}

Berdasarkan hasil uji regresi didapati hasil sebagai berikut.

Model Summary ${ }^{\mathrm{b}}$

Tabel 4 Uji R Square

\begin{tabular}{|l|l|l|l|l|l|l|l|}
\hline Model & $\mathrm{R}$ & $\mathrm{R}$ Square & $\begin{array}{l}\text { Adjusted } \\
\text { Square }\end{array}$ & $\begin{array}{l}\mathrm{R} \\
\text { Std. Error of the } \\
\text { Estimate }\end{array}$ & & \multicolumn{4}{|l|}{ Change Statistics } \\
\cline { 6 - 8 } & & & R Square Change & F Change & df1 \\
\hline 1 & $961^{\mathrm{a}}$ & .923 & .885 & .05874 & .923 & 24.002 & 2 \\
\hline
\end{tabular}

a. Predictors: (Constant), belanja langsung, belanja tidak langsung

b. Dependent Variable: sektor keuangan real estate, dan jasa perusahaan

Dalam melihat pengaruh Variabel Independen Exogenus belanja tidak langsung dan belanja langsung secara bersama-sam terhadap variabel Dependen Endogenus sektor keuangan, real estate dan jasa perusahaan dapat dilihat pada Tabel 4.3 Model Summary diatas, pada nilai R square. Besarnya R square (R2) pada tabel dibawah ini adalah 0,978. Angka tersebut mempumpunyai makna Besarnya pengaruh Variabel independen exogenous belanja tidak langsung dan belanja langsung terhadap variabel dependen endogenus sektor keuangan, real estate dan jasa perusahaan secara gabungan. Dalam menghitung Koefisien Determinasi (KD) dapat diketahui dengan rumus :

$\mathrm{KD}=\mathrm{R} 2 \times 100 \%$

$\mathrm{KD}=0,885 \times 100 \%$

$\mathrm{KD}=88,5 \%$

Besarnya pengaruh Variabel Independen belanja tidak langsung dan belanja langsung terhadap Variabel sektor keuangan, real estate dan jasa perusahaan secara gabungan adalah 97,8\%. Dan pengaruh diluar model dapat di hitung dengan :

$\mathrm{e}=1-\mathrm{R}^{2}$

$\mathrm{e}=1-0,885$

$\mathrm{e}=0,115 \times 100 \%$

$\mathrm{e}=11,5 \%$

Yang berarti 11,5\% besarnya faktor lain yang mempengaruhi diluar model yang di teliti. Artinya besarnya pengaruh variabel independen belanja tidak langsung dan belanja langsung terhadap variabel dependen sektor keuangan, real estate dan jasa perusahaan adalah sebesar 88,5\%, sedangkan pengaruh sebesar 11,5\% disebabkan oleh variabel di luar model yang di teliti.

Coefficients $^{\mathrm{a}}$

\section{Tabel 5 Uji Coeficient Beta}

\begin{tabular}{|ll|l|l|l|l|l|}
\hline \multirow{2}{*}{ Model } & \multicolumn{2}{|l|}{ Unstandardized Coefficients } & $\begin{array}{l}\text { Standardized } \\
\text { Coefficients }\end{array}$ & & \multirow{2}{*}{ Sig. } \\
\cline { 2 - 5 } & & $\mathrm{B}$ & Std. Error & Beta & & \\
\hline \multirow{2}{*}{1} & (Constant) & -10.636 & 2.530 & & -4.204 & .014 \\
& belanja tidak langsung & 1.264 & .283 & .878 & 4.466 & .011 \\
& belanja langsung & .166 & .290 & .112 & .571 & .599 \\
\hline
\end{tabular}

Pengaruh Variabel Independen belanja langsung terhadap peningkatan sektor keuangan, real estate dan jasa perusahaan

Untuk melihat apakah ada Pengaruh Linier Variabel Independen Exogenus belanja langsung terhadap Variabel Dependen Endogenus sector keuangan, real estate dan jasa perusahaan. Dapat dilihat pada tabel 4.4 Coefficients(a).

Menentukan besarnya taraf Signifikan sebesar 0,05 dan Degree of Freedom DF $=\mathrm{n}-(\mathrm{K}+1)$ atau DF $=7-$ $(2+1)=4$. Dari ketentuan tersebut diperoleh $t$ tabel sebesar 1,837 (untuk uji dua arah).

Dalam perhitungan SPSS yang tertera pada tabel Coefficients di atas dimana tabel $t$ adalah untuk menunjukan bahwa adanya Pengaruh linier antara Variabel Independen belanja langsung terhadap Variabel sector keuangan, real estate dan jasa perusahaan ialah 0,571.

Menghitung besarnya angka $t$ tabel / nilai kritis dengan ketentuan sebagai berikut: 
Pengujian Hipotesis t kriterianya sebagai berikut :

1. Jika t hitung $>\mathrm{t}$ tabel, maka $\mathrm{H} 0$ ditolak, dan $\mathrm{H} 1$ diterima

2. Jika t hitung $<\mathrm{t}$ tabel, maka $\mathrm{HO}$ diterima, dan $\mathrm{H} 1$ ditolak

Dimana dalam melihat pengaruh signifikan atau tidak Kriterianya adalah sebagai berikut :

1. Jika Signifikan $<0,05$ maka berpengaruh signifikan

2. Jika Signifikan $>0,05$ maka tidak ada pengaruh signifikan

Hasil dari perhitungan dengan SPSS menunjukan angka t hitung sebesar 0,571< t tabel sebesar 1,837. Dengan demikian keputusanya ialah H0 diterima dan H1 ditolak. Artinya tidak ada pengaruh linear antara variable independen belanja langsung terhadap variable Variabel dependen sector keuangan, real estate dan jasa perusahaan.

Besarnya pengaruh Variabel Independen Exogenus belanja langsung terhadap Variabel Dependen Variabel sector keuangan, real estate dan jasa perusahaan diketahui dari nilai Koefisien Beta (dalam kolom Standardized Coefficients Beta) ialah 0,878 tidak Signifikan karena nilai signifikansi / probabilitas hasil yang tertera pada kolom Sig $0,11>0,05$.

\section{Pengaruh Variabel Independen tidak belanja langsung terhadap peningkatan sektor keuangan, real estate dan jasa perusahaan}

Untuk melihat apakah ada Pengaruh Linier Variabel Independen Exogenus belanja tidak langsung terhadap Variabel Dependen Endogenus sektor keuangan, real estate dan jasa perusahaan. Dapat dilihat pada tabel 4.4 Coefficients(a).

Menentukan besarnya taraf Signifikan sebesar 0,05 dan Degree of Freedom DF $=\mathrm{n}-(\mathrm{K}+1)$ atau $\mathrm{DF}=7-$ $(2+1)=4$. Dari ketentuan tersebut diperoleh t tabel sebesar 1,837 (untuk uji dua arah).

Dalam perhitungan SPSS yang tertera pada tabel Coefficients di atas dimana tabel t adalah untuk menunjukan bahwa adanya Pengaruh linier antara Variabel Independen belanja langsung terhadap Variabel sector keuangan, real estate dan jasa perusahaan ialah 4.466.

Menghitung besarnya angka t tabel / nilai kritis dengan ketentuan sebagai berikut:

Pengujian Hipotesis t kriterianya sebagai berikut :

1. Jika t hitung $>\mathrm{t}$ tabel, maka $\mathrm{H} 0$ ditolak, dan $\mathrm{H} 1$ diterima

2. Jika t hitung < t tabel, maka H0 diterima, dan H1 ditolak

Dimana dalam melihat pengaruh signifikan atau tidak Kriterianya adalah sebagai berikut :

1. Jika Signifikan $<0,05$ maka berpengaruh signifikan

2. Jika Signifikan $>0,05$ maka tidak ada pengaruh signifikan

Hasil dari perhitungan dengan SPSS menunjukan angka t hitung sebesar $4.466>\mathrm{t}$ tabel sebesar 1,837. Dengan demikian keputusanya ialah H0 diterima dan H1 ditolak. Artinya tidak ada pengaruh linear antara variable independen belanja tidak langsung terhadap variable Variabel dependen sector keuangan, real estate dan jasa perusahaan.

Besarnya pengaruh Variabel Independen Exogenus belanja langsung terhadap Variabel Dependen Variabel sector keuangan, real estate dan jasa perusahaan diketahui dari nilai Koefisien Beta (dalam kolom Standardized Coefficients Beta) ialah 0,112 tidak Signifikan karena nilai signifikansi / probabilitas hasil yang tertera pada kolom Sig 0,599>0,05

\section{Melihat Kelayakan Model Regresi}

Untuk mengetahui model regresi yang telah dibuat sudah benar adalah dengan menggunakan pengujian dengan dua cara, yaitu Pertama menggunakan nilai F pada tabel keluaran ANOVA, dan Kedua dengan cara menggunakan nilai Probabilitas /nilai Sig pada tabel 4.6 keluaran ANOVA.

Tabel 6 Kelayakan Model Regresi

ANOVA $^{\mathrm{a}}$

\begin{tabular}{|ll|l|l|l|l|l|}
\hline Model & & Sum of Squares & df & Mean Square & F & Sig. \\
\hline \multirow{2}{*}{1} & Regression & .166 & 2 & .083 & 24.002 & $.006^{\mathrm{b}}$ \\
& Residual & .014 & 4 & .003 & & \\
& Total & .179 & 6 & & & \\
\hline
\end{tabular}

a. Dependent Variable: sektor keuangan real estate, dan jasa perusahaan

b. Predictors: (Constant), belanja langsung, belanja tidak langsung

Sumber Data : Pengolahan Data 2015 
Menghitung nilai $\mathrm{F}$ tabel dengan Ketentuan besar nilai taraf Signifikansi sebesar 0,05 dan Nilai Degree Of Freedom dengan ketentuan Numerator / Vektor 1: Jumlah Variabel -1 atau $3-1=2$, dan dumerator / Vektor 2 : jumlah kasus-jumlah variabel atau $7-3=4$. Dengan ketentuan terdebut diperoleh angka $F$ tabel sebesar 6.942 Dengan kriteria pengambilan keputusan hasil pengujian hipotesis

Jika F hitung $>\mathrm{F}$ tabel, maka H0 ditolak, H1 diterima.

Jika F hitung < F tabel, maka H0 diterima dan H1 ditolak.

Hasil uji hipotesis adalah :

Hasil perhitungan dengan SPSS didapatkan angka F hitung sebesar 24.002> F tabel sebesar 6,942. Dengan demikian $\mathrm{H} 0$ ditolak, dan H1 diterima. Artinya ada hubungan linier antara Variabel Independen Eksogenus belanja langsung dan belanja tidak langsung dengan Variabel Dependen Endogenus sub-sektor transportasi. Dengan nilai Sig 0,006 Kesimpulan adalah model regresi di atas sudah layak dan benar.

\section{Pembahasan}

Dari hasil penelitian yang dilakukan didapatkan hasil bahwa alokasi anggaran belanja langsung pemerintah tidak member kontribusi yang positif dan signifikan terhadap peningkatan sector keuangan, real estate dan jasa perusahaan apabaila dilakukan uji secara parsial, hal ini member indikasi bahwa alokasi anggaran belanja langsung pemerintah belum banyak member pengaruh terhadap peningkatan yang terjadi pada sector yang diteliti, sedangkan seharusnya pemerintah mempunyai peran serta andil yang besar bagi peningkatan atau pertumbuhan ekonomi di daerah yang bersangkutan dan hal ini bias terwujud apabila pemerintah juga focus dalam mengembangkan sector-sektor ekonomi yang ada di daerah sehingga juga dapat member kontribusi pada agregat pendapatan daerah.

Sedangkan untuk alokasi anggaran belanja tidak langsung, mempunyai korelasi positif dengan pertumbuhan sector ekonomi keuangan, real estate dan jasa keuangan serta mempunyai signifikansi positif dengan sector ekonomi yang diteliti sehingga bias disimpulkan bahwa pemerintah mempunyai andil dalam pembangunan sector ekonomi namun, tidak melalui alokasi anggaran investasi tapi secara tidak langsung melalui pengembangan sector-sektor ekonomi yang ada dibawahnya, namun melalui alokasi anggaran yang dianggarkan untuk hibah, social dan lain-lain yang secara otomatis meningkatkan kesejahteraan dan kemampuan beli masyarakat. Sedangkan apabila dua alokasi anggaran ini digabungkan ternyata memberikan ouput hasil yang amat besar dan signifikan terhadap peningkatan yang terjadi pada sector ekonomi yang diteliti.

\section{Kesimpulan}

\section{BAB V \\ PENUTUP}

Dari hasil penelitian didapatkan hasil baik belanja langsung maupun belanja tidak langsung mempunyai pengaruh yang sangat signifikan terhadap pertumbuhan ekonomi sector keuangan, real estate, dan jasa perusahaan, hal ini dapat dilihat dari titik $\mathrm{R}$ square yang mencapai angka .885 atau yang bisa diartikan dengan 88,5 persen tingkat pengaruh kedua alokasi belanja pemerintah terhadap peningkatan sector ekonomi yang diteliti. Hal ini tentu merupakan sebuah gambaran nyata bahwa pertumbuhan yang terjadi di sector-sektor ekonomi potensial masih amat bergantung pada alokasi anggaran belanja yang dikeluarkan pemerintah. Semestinya pertumbuhan-pertumbuhanyang terjadi di sector ekonomi perlu ada campur tangan juga dari pihak swasta sehingga tidak serta merta bergantung pada pemerintah.

\section{Saran}

Berdasarkan hasil penelitian pengaruh belanja langsung dan tidak langsung terhadap peningkatan ekonomi sector keuangan, real estate dan jasa perusahaan penulis coba memberikan saran :

Mempertahankan kinerja pengelolaan yang sudah tertata dengan baik di pemerintah kota Manado, terlebih dalam pengelolaan sumber-sumber ekonomi potensial yang kemudian akan dijadikan bahan untuk menggenjot perekonomian secara keseluruhan..

Membuka sector-sektor ekonomi potensial yang dapat menjadi sumber-sumber pendapatan daerah agar dapat meningkatkan taraf kemandiriannya dan tidak terlalu bergantung pada kucuran dana dari pemerintah pusat dalam bentuk dana transfer, dan dengan adanya sumber-sumber ekonomi baru ini diharapkan belanja pembangunan yang dilakukan oleh pemerintah Kota Manado akan bisa berkembang lebih baik lagi dan tentunya menjadi salah satu sarana bagi pemerintah untuk mengurangi tingkat kemiskinan karena dengan 
adanya sumber perekonomian yang baru maka tentunya akan menyerap tenaga kerja yang belum bisa terserap sebelumnya karena kurangnya kesempatan kerja.

\section{DAFTAR PUSTAKA}

Ahmad, Yani. (2002). Hubungan Keuangan Antara Pemerintah Pusat dan Daerah. Jakarta: Grafindo. Ardi Hamzah, 2006. Analisis Kinerja Keuangan Terhadap Pertumbuhan Ekonomi Pengangguran dan Kemiskinan,(studi pada 29 kota kabupaten dan 9 kota di Propinsi Jawa Timur periode 2001-2006). Anna Yulianita,2008. Analisis Sektor Unggulan dan pengeluaran Pemerintah di Kabupaten Ogan Komering Ilir,

Bastian, Indra, Gatot Soepriyanto, 2002. Sistem Akuntansi Sektor Publik Konsep Untuk Pemerintah Daerah, Edisi Pertama, Salemba Empat, Jakarta.

Gujarati, Damodar. 2003. Ekonometrika Dasar : Edisi Keenam. Jakarta: Erlangga.

Ghozali, Imam. 2006. “Aplikasi Analisis Multivariate Dengan Program SPSS”.Semarang : Badan Penerbit Undip

Halim, Abdul. 2004, Pengelolaan Keuangan Daerah, Seri Bunga Rampai Manajemen Keuangan Daerah, UPP STIM YKPN, Yogyakarta.

Halim, Abdul. 2002, Akuntansi Sektor Publik Akuntansi Keuangan Daera, Edisi pertama. Jakarta :

Salemba Empat.

Halim, Abdul, 2004. Akuntansi Keuangan Daerah, Penerbit Salemba Empat, Jakarta.

Mardiasmo. 2004. Akuntansi Sektor Publik. Penerbit Andi. Yogyakarta.

Rostow, Walt, W. 1960, the stage of economics growth: A non-Comunist Manifesto. London Cambridge University Press.

Santoso Singgih, 2002. Mengolah Data Statistik Secara Prefesional, Jakarta: Penerbit PT Elex Media Komputindo, hlm 143-231.

Santoso Singgih, 2001. Statistik Multivariat, Jakarta: Penerbit PT Elex Media Komputindo, hlm 378-452. Saragih, Juli Panglima. 2003. Desentralisasi Fiskal dan Keuangan Daerah dalam Otonomi. Cetakan Pertama. Penerbit Ghalia Indonesia: Jakarta

Sadono Sukirno, 2006, Ekonomi Pembangunan Proses masalah dan Dasar Kebijakan, cetakan ketiga, Penerbit Kencana, Jakarta.

Solow, Robert 1956. "A Contribution to the teory of economic growth. "Quaterly Journal of economics 70. Santoso, Singgih dan Tjiptono, Fandy, 2001, Riset Pemasaran: Konsep dan Aplikasi dengan SPSS, PT Elex Media Komputindo, Jakarta.

Sekaran, Uma. 1992. "Research Methods for Business". Third Edition. Southern Illionis University. Tonny Judianto, 2005. Analisis Indikator Transportasi Jalan Raya dan Pertumbuhan Ekonomi di Provinsi jawa Barat,

-Peraturan Menteri Dalam Negeri No. 13 Tahun 2006 tentang Pengelolaan Keuangan Daerah -Surat Mendagri dan Otonomi Daerah No. 903 Tahun 2000 tentang Pedoman Umum

Penyusunan dan Pelaksanaan APBD tahun Anggaran 2001

-Keputusan Menteri Dalam Negeri No. 29 Tahun 2002

-PP RI No. 105 Tahun 2000 tentang Pengelolaan dan Pertanggungjawaban Keuangan Daerah -------------Undang-Undang No 33 Tahun 2004 tentang perimbangan keuangan antara pemerintah pusat dan daerah

---------------Undang-Undang No.32 Tahun 2004 tentang pemerintahan daerah 2007 